\title{
Parametry echokardiograficzne wpływające na rokowanie pacjentów z kardiomiopatią takotsubo
}

\author{
Echocardiographic factors influencing outcome \\ in patients with takotsubo cardiomyopathy
}

\author{
Monika Budnik \\ I Katedra i Klinika Kardiologii Warszawskiego Uniwersytetu Medycznego
}

\begin{abstract}
Streszczenie
Kardiomiopatia takotsubo to odwracalna dysfunkcja skurczowa lewej komory, której objawy przypominają ostry zespół wieńcowy. Rokowanie jest na ogół korzystne - w ciągu kilku tygodni dochodzi do poprawy funkcji skurczowej lewej komory, jednak czasami występują powikłania, takie jak ostra niedomykalność mitralna, dysfunkcja prawej komory, zawężanie drogi odpływu lewej komory, skrzeplina w lewej komorze, ostra niewydolność serca lub wstrząs kardiogenny, które mogą nawet prowadzić do zgonu. Dlatego niezwykle istotne jest znalezienie czynników, które wpływają na rokowanie pacjentów, a które są łatwo i szybko dostępne.
\end{abstract}

Słowa kluczowe: takotsubo, zespół balotującego koniuszka, kardiomiopatia stresowa

Folia Cardiologica 2016; 11, 6: 569-574

\section{Wstęp}

Kardiomiopatia takotsubo (TTC, takotsubo cardiomyopathy) to nagła, odwracalna dysfunkcja skurczowa lewej komory (LV, left ventricle), której objawy przypominają ostry zespół wieńcowy (ACS, acute coronary syndrome) [1, 2]. Większość pacjentów to kobiety w wieku pomenopauzalnym, a najstarszy na świecie opisany przypadek dotyczył pacjentki w wieku 98 lat [3]. Objawy i obraz EKG przypominają ACS, a w badaniach laboratoryjnych stwierdza się wysoki stosunek N-końcowego fragmentu propeptydu natriuretycznego typu B (NT-proBNP, N-terminal pro-B-type natriuretic peptide) do troponiny I (Tnl) [4]. Częstość nawrotów waha się między 0 a 15\% [5, 6]. Istnieje udokumentowany przypadek pacjentki, u której choroba wystąpiła 4-krotnie [7]. W większości przypadków rokowanie jest korzystne, u niektórych chorych jednak dochodzi do groźnych powikłań, które mogą być nawet przyczyną zgonu [8-14].

\section{Rokowanie krótkoterminowe}

U pacjentów z TTC szybko dochodzi do poprawy funkcji LV - w ciągu kilku dni lub tygodni. Niestety w ostrej fazie choroby może dojść do wielu powikłań, takich jak ostra niewydolność serca, obrzęk płuc, wstrząs kardiogenny, ostra niedomykalność mitralna (MR, mitral regurgitation), dysfunkcja prawej komory (RV, right ventricle), zawężanie drogi odpływu LV, skrzeplina w LV, pęknięcie LV, przegrody międzykomorowej lub zaburzenia rytmu serca. Większość publikacji ocenia śmiertelność krótkoterminową na 2-3\% $[13,15,16]$, jednak w niektórych badaniach sięga ona 8,9\% [17]. W dużym rejestrze obejmującym 24701 pacjentów śmiertelność wewnątrzszpitalna wynosiła 4,2\% [18].

Czynnikami, które miały wpływ na śmiertelność wewnątrzszpitalną, były: wiek, wstrząs, frakcja wyrzutowa (EF, ejection fraction) [19] oraz stan kliniczny przy przyjęciu do szpitala [20]. Częstość występowania powikłań zarówno 
w trakcie hospitalizacji, jak i po wypisie była wyższa w grupie pacjentów, którzy byli w klasie Killipa równej 2 lub wyższej. Również średnia długość hospitalizacji była większa w tej grupie chorych [13]. Główną przyczyną zgonów w szpitalu u pacjentów z TTC były choroby współistniejące [18].

Na rokowanie pacjentów z TTC może mieć wpływ rodzaj czynnika wywołującego objawy. U osób, u których czynnikiem wywołującym TTC był czynnik psychiczny oraz u których nie udało się znaleźć czynnika sprawczego, częściej występowała konieczność zastosowania leków inotropowych i diuretycznych, a także pacjenci ci wymagali dłuższego pobytu na oddziale intensywnej terapii oraz dłużej pozostawiali w szpitalu [21]. Również płeć męska wiązała się z większą śmiertelnością wewnątrzszpitalną [18].

Wewnątrzszpitalna śmiertelność była wyższa w grupie pacjentów, u których wystąpiła jakakolwiek arytmia w trakcie hospitalizacji niż w grupie bez arytmii (7,4\% v. 3,6\%). Ponadto długość hospitalizacji była wyższa w grupie chorych, u których wystąpiła artymia (8 v. 6,5 dnia). Podobna zależność występowała w kosztach hospitalizacji [22].

U pacjentów z migotaniem przedsionków, zarówno rozpoznanym przed hospitalizacją, jak i ze świeżo rozpoznanym, częściej występowały wstrząs kardiogenny i zagrażające życiu arytmie w porównaniu z chorymi bez migotania. Również śmiertelność wewnątrzszpitalna była wyższa w tej grupie osób [23].

\section{Rokowanie długoterminowe}

Rokowanie długoterminowe w TTC wydaje się korzystne ze względu na szybką poprawę funkcji skurczowej LV w ciągu kilku tygodni. W dwóch badaniach porównujących śmiertelność długoterminową w TTC uzyskano jednak odmienne wyniki. Według Vriz i wsp. [24] śmiertelność długoterminowa wynosiła 9\% w ciągu 2,6 roku i była spowodowana chorobami współistniejącymi. Żaden ze zgonów nie był z przyczyn sercowo-naczyniowych, co może sugerować, że śmiertelność w tej grupie chorych nie miała związku z wystąpieniem TTC [24]. Parodi i wsp. [15] wskazali natomiast, że pacjenci z TTC mają 3-krotnie wyższe ryzyko zgonu niż w populacji ogólnej. Wydaje się, że długoterminowe rokowanie u pacjentów z TTC jest lepsze niż u chorych z zawałem serca z uniesieniem odcinka ST, a gorsze niż w populacji ogólnej [24].

Czynnikami wpływającymi na rokowanie odległe u pacjentów z TTC były: płeć męska, klasa Killipa 3/4, cukrzyca [25], konieczność zastosowania intubacji w trakcie hospitalizacji oraz skorygowany odstęp QT przy przyjęciu do szpitala. Krótszy skorygowany odstęp QT był związany z wyższym ryzykiem zgonu w czasie obserwacji odległej [26].

Istnieją odmienne dane dotyczące wpływu wyjściowej funkcji LV na rokowanie odległe. Parodi i wsp. [15] stwierdzili, że śmiertelność długoterminowa nie zależy od wyjściowej funkcji LV ocenianej przy przyjęciu do szpitala. Jedynym czynnikiem predykcyjnym śmiertelności u pacjentów z TTC były choroby współistniejące [15]. Jednak w innym badaniu wykazano, że EF mniejsza niż 45\%, migotanie przedsionków oraz obecność choroby neurologicznej były niezależnymi czynnikami zwiększonej śmiertelności rocznej [27].

Śmiertelność 30-dniowa oraz 3-letnia były wyższe w grupie z migotaniem przedsionków. Złożony punkt końcowy w postaci powikłań zakrzepowo-zatorowych, zagrażających życiu arytmii, śmiertelności z jakiejkolwiek przyczyny, rehospitalizacji z powodu niewydolności serca, udaru mózgu oraz nawrotu TTC wystąpił częściej u pacjentów z migotaniem i z EF nie wyższą niż 35\% [23]. Mniejsza, ale nieistotna statystycznie śmiertelność w obserwacji długoterminowej była obserwowana w grupie pacjentów, którzy otrzymali beta-adrenolityk przy wypisie ze szpitala, w porównaniu z pacjentami, u których nie zalecono beta-adrenolityku. Natomiast u chorych, którzy byli leczeni beta-adrenolitykiem, odnotowano częstsze rehospitalizacje, głównie z powodów pozakardiologicznych [15].

\section{Parametry echokardiograficzne}

Pierwszym powszechnie dostępnym i nieinwazyjnym badaniem obrazowym wykonywanym u pacjenta z podejrzeniem TTC jest echokardiografia (ryc. 1). Pozwala na ocenę funkcji LV i RV oraz na wykrycie powikłań, takich jak zawężanie drogi odpływu LV, skrzeplina w LV, ostra MR. Już sama wartość EF - stosunkowo prostego parametru - jest niezależnym czynnikiem poważnych powikłań w trakcie hospitalizacji i stanowi jeden z markerów służących do wczesnej identyfikacji pacjentów wysokiego ryzyka rozwinięcia ostrej niewydolności serca [28].

\section{Ocena kurczliwości}

Ocena kurczliwości mięśnia LV pozwala zakwalifikować pacjentów z TTC do jednej z grup na podstawie typu zaburzeń kurczliwości: typowe, jeśli dotyczy segmentów koniuszkowych, odwrócone, jeśli zajęte są segmenty postawne oraz dotyczące segmentów środkowych LV. W jednym z badań oceniających wpływ typu TTC na rokowanie krótko- i długoterminowe okazało się, że mimo młodszego wieku, wyższej EF, niższych wartości BNP u pacjentów z atypową postacią TTC częstość występowania wstrząsu kardiogennego, groźnych arytmii oraz śmiertelności wewnątrzszpitalnej była taka sama jak u pacjentów z koniuszkową formą TTC. W długoterminowej obserwacji wykazano porównywalną częstość poważnych zdarzeń sercowo-naczyniowych oraz incydentów mózgowo-naczyniowych u pacjentów z typową i atypową formą TTC. Rodzaj TTC nie był również niezależnym czynnikiem wpływającym na śmiertelność roczną [27]. 


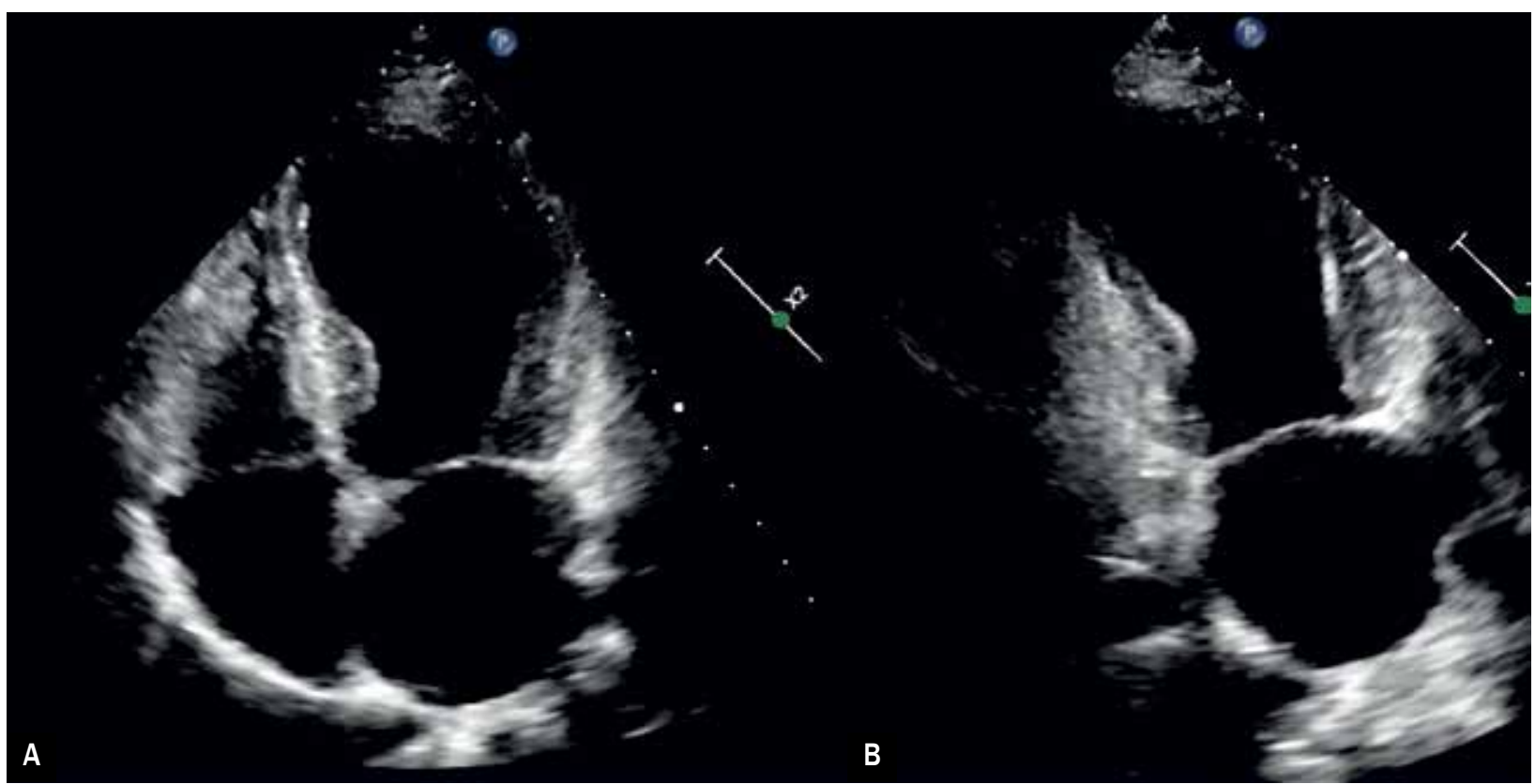

Rycina 1A, B. Koniuszkowy (klasyczny) typ kardiomiopatii takotsubo (materiał I Katedry i Kliniki Kardiologii Warszawskiego Uniwersytetu Medycznego)

W innym badaniu na podstawie analizy śmiertelności według różnych typów TTC (koniuszkowy v. atypowy) wskazano na trend w kierunku zwiększonej 28-dniowej śmiertelności u pacjentów z typowym TTC, ale nie osiągnięto istotności statystycznej. Natomiast 6-miesięczna i długoterminowa śmiertelność była istotnie wyższa u chorych z typowym TTC niż atypowym. Różnica wynikała ze zwiększonej śmiertelności z przyczyn sercowo-naczyniowych, podczas gdy śmiertelność z przyczyn innych niż sercowo-naczyniowe nie różniła się istotnie. W analizie wieloczynnikowej wstrząs kardiogenny i typ koniuszkowy TTC były predyktorami zwiększonej 6-miesięcznej śmiertelności [29].

\section{Zawężanie drogi odpływu lewej komory}

Zawężanie drogi odpływu LV może być spowodowane wzmożoną kurczliwością segmentów podstawnych ścian LV pod wpływem katecholamin. U pacjentów z ciężką dysfunkcją skurczową LV może predysponować do wstrząsu kardiogennego, zwłaszcza w przypadku zastosowania leków adrenergicznych lub diuretyków. Dlatego niezwykle ważna jest wczesna diagnoza w celu doboru optymalnego postępowania farmakologicznego lub nawet zastosowania kontrapulsacji wewnątrzaortalnej (IABP, intra-aortic balloon pump). W rejestrze włoskim zawężanie częściej występowało u pacjentów, u których wystąpiły powikłania w trakcie hospitalizacji [30]. Ponadto może być związane z systolicznym ruchem przedniego płatka zastawki mitralnej w kierunku przegrody międzykomorowej (SAM, systolic anterior motion), prowadząc do niedomykalności mitralnej [31].

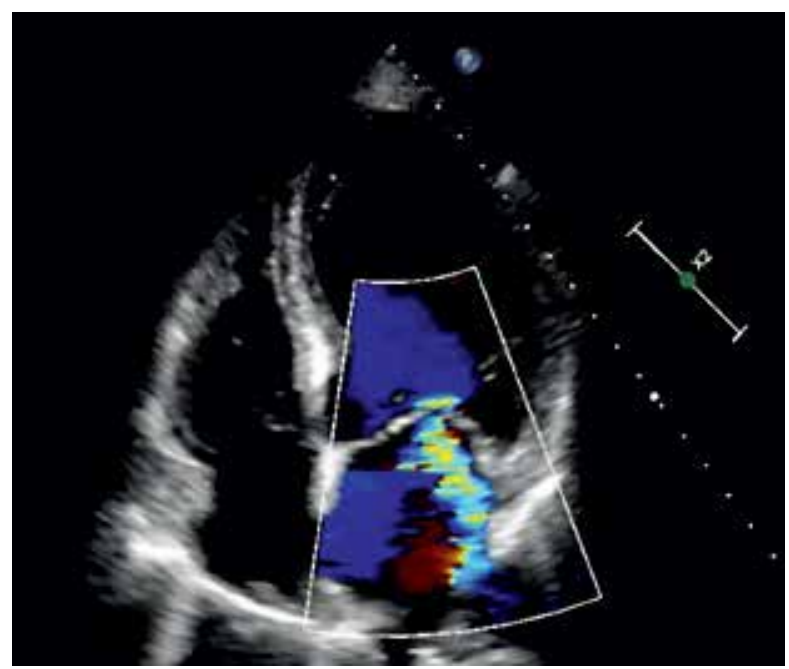

Rycina 2. Ostra czynnościowa niedomykalność mitralna u pacjentki z kardiomiopatią takotsubo (materiał I Katedry i Kliniki Kardiologii Warszawskiego Uniwersytetu Medycznego)

\section{Niedomykalność zastawki mitralnej}

Istotna czynnościowa MR (ryc. 2) pojawia się u około 1/5 pacjentów z TTC i jest związana ze stopniem nasilenia objawów ostrej niewydolności serca ocenianej według skali Killip. Czynnikami predysponującymi do wystąpienia ostrej MR u pacjentów z TTC była EF przy przyjęciu i SAM [32]. Niedomykalność zastawki mitralnej była markerem prognostycznym związanym ze wstrząsem kardiogennym i zwiększoną śmiertelnością wewnątrzszpitalną [29]. 


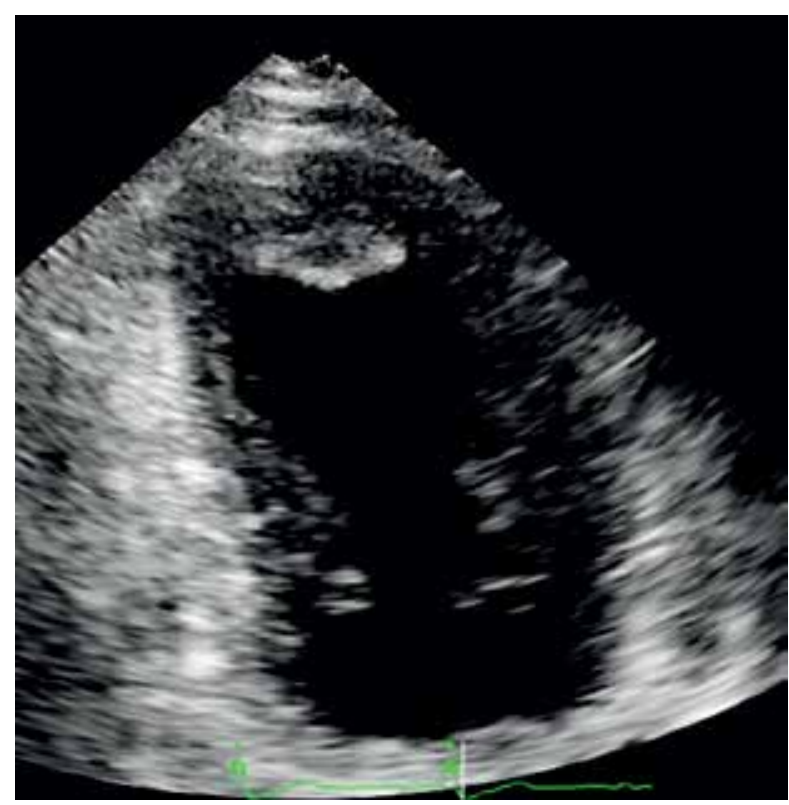

Rycina 3. Skrzeplina w koniuszku lewej komory u pacjentki z kardiomiopatią takotsubo (materiał I Katedry i Kliniki Kardiologii Warszawskiego Uniwersytetu Medycznego)

Jednak niektóre badania nie potwierdzają negatywnego wpływu ostrej MR na rokowanie pacjentów [33].

\section{Skrzeplina w lewej komorze}

Skrzeplina w lewej komorze (ryc. 3) jest opisywana u 1-2\% pacjentów z TTC $w$ ciągu pierwszych dwóch dni hospitalizacji, powodując powikłania w postaci zatorów obwodowych u 1/3 chorych [34].

\section{Ocena funkcji rozkurczowej}

Spośród parametrów oceniających funkcję rozkurczową LV wartość E/e' była większa u pacjentów, u których doszło do poważnych powikłań w trakcie hospitalizacji i była niezależnym czynnikiem predykcyjnym wystąpienia ostrej niewydolności serca i zwiększenia śmiertelności wewnątrzszpitalnej. Dlatego E/e' powinno być mierzone jak najszybciej i wielokrotnie powtarzane u pacjentów z TTC w celu zidentyfikowania pacjentów wysokiego ryzyka [30].

Również wartość fali E, stosunek E/A, DT oraz e' stwierdzane przy przyjęciu do szpitala różniły się u pacjentów, u których doszło do poważnych powikłań w trakcie hospitalizacji pod postacią ostrej niewydolności serca, wstrząsu kardiogennego i zgonu z przyczyn kardiologicznych. W obserwacji krótkoterminowej (4-6 tygodni) istotnie wyższymi parametrami u pacjentów, u których wystąpiły powikłania w stosunku do chorych bez powikłań, były: objętość lewego przedsionka (LA, left atrial), prędkość fali $E$, stosunek $E / A$, prędkość e', stosunek E/e'

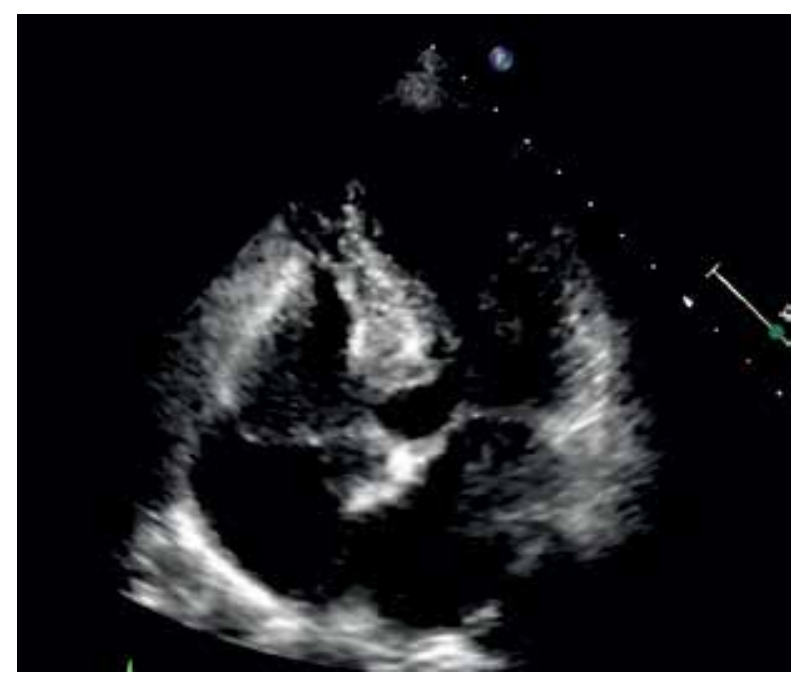

Rycina 4. Dysfunkcja skurczowa prawej komory u pacjentki z kardiomiopatią takotsubo (materiał I Katedry i Kliniki Kardiologii Warszawskiego Uniwersytetu Medycznego)

i ciśnienie skurczowe w tętnicy płucnej (sPAP, systolic pulmonary arteria pressure) [30].

\section{Dysfunkcja prawej komory}

Częstość występowania dysfunkcji RV (ryc. 4) w rejestrach wynosi 14,5\% [30] i stanowi dodatkowy parametr różnicujący TTC od zawału serca ściany przedniej. Istnieją doniesienia, że dysfunkcja RV jest związana z wyższą częstością rozwoju niewydolności serca, konieczności resuscytacji krążeniowo-oddechowej, zastosowania IABP i dłuższą hospitalizacją [35] oraz występowała częściej u pacjentów, u których doszło do poważnych powikłań wewnątrzszpitalnych [30]. Chorzy, u których doszło do dysfunkcji RV w przebiegu TTC, częściej mieli niewydolność serca definiowaną jako klasa Killip równa 3 lub wyższa, wymagali częściej intubacji i hospitalizacji na oddziale intensywnej terapii. Zgony wystąpiły istotnie częściej w grupie chorych z dysfunkcją RV, ale dotyczyło to tylko niewielkiej liczby pacjentów (3 v. 1), z czego jeden chory zmarł z powodu pęknięcia serca, jeden z powodu migotania komór, a jeden z powodu choroby współistniejącej (chłoniak złośliwy). W obserwacji długoterminowej obejmującej 709 dni 21,2\% pacjentów osiągnęło złożony punkt końcowy (zgon z jakiejkolwiek przyczyny, rehospitalizacja z powodu niewydolności serca oraz nawrót TTC). Przeżycie wolne od wymienionych zdarzeń niepożądanych było krótsze w grupie pacjentów z obukomorową TTC niż bez dysfunkcji RV. W analizie wieloczynnikowej dysfunkcja RV była jedynym predyktorem wystąpienia punktu końcowego [36]. W kolejnym badaniu stwierdzono, że dysfunkcja RV była predyktorem zgonu [37]. W innym badaniu jednak nie wykazano zależności między wystąpieniem dysfunkcji RV a śmiertelnością krótkoterminową [38]. 


\section{Podsumowanie}

Na podstawie licznych badań można stwierdzić, że istnieją parametry, które pozwalają przewidzieć zarówno rokowanie krótko-, jak i długoterminowe u pacjentów z TTC. Ich znalezienie jest niezwykle pomocne, gdyż pozwala wcześnie zakwalifikować pacjenta do grupy wysokiego ryzyka wystąpienia powikłań i umożliwia ściślejsze monitorowanie tej grupy chorych.

\section{Abstract}

Takotsubo cardiomyopathy is a reversible left ventricular systolic dysfunction which mimics acute myocardial infarction. The prognosis is generally favorable with improvement of left ventricular function in a few weeks. However, serious complications, such as acute mitral regurgitation, dysfunction of the right ventricular, left ventricular outflow tract obstruction, left ventricular thrombus, acute heart failure, cardiogenic shock can occur which can even fatal. It is therefore extremely important to determine easy and quickly accessible factors that affect the prognosis.

Key words: takotsubo, apical ballooning syndrome, stress-induced cardiomyopathy

Folia Cardiologica 2016; 11, 6: 569-574

\section{Piśmiennictwo}

1. Bybee K.A., Kara T., Prasad A. i wsp. Systematic review: transient left ventricular apical ballooning: a syndrome that mimics ST-segment elevation myocardial infarction. Ann. Intern. Med. 2004; 141: 858-865.

2. Gianni M., Dentali F., Grandi A.M. i wsp. Apical ballooning syndrome or takotsubo cardiomyopathy: a systematic review. Eur. Heart J. 2006; 27: 1523-1529.

3. Budnik M., Piatkowski R., Kochanowski J. i wsp. The oldest patient with takotsubo cardiomyopathy. J. Geriatr. Cardiol. 2015; 12: 588-589 .

4. Budnik M., Kochanowski J., Piatkowski R. i wsp. Simple markers can distinguish Takotsubo cardiomyopathy from ST segment elevation myocardial infarction. Int. J. Cardiol. 2016; 219: 417-420.

5. Tsuchihashi K., Ueshima K., Uchida T. i wsp. Transient left ventricular apical ballooning without coronary artery stenosis: a novel heart syndrome mimicking acute myocardial infarction. J. Am. Coll. Cardiol. 2001; 38: 111-118.

6. Sharkey S., Windenburg D., Lesser J. i wsp. Natural history and expansive clinical profile of stress (takotsubo) cardiomyopathy. J. Am. Coll. Cardiol. 2010; 55: 333-341.

7. Opolski G., Budnik M., Kochanowski J. i wsp. Four episodes of takotsubo cardiomyopathy in one patient. Int. J. Cardiol. 2016; 203: 53-54.

8. Citro R., Rigo F., Previtali M. i wsp. Differences in clinical features and in-hospital outcomes of older adults with takotsubo cardiomyopathy. J. Am. Geriatr. Soc. 2012; 60: 93-98.

9. Vriz O., Driussi C., Fazio M.G. i wsp. Takotsubo cardiomyopathy: insights from a community hospital. J. Cardiovasc. Med. 2013; 14: 576-581.

10. Samardhi H., Raffel O.C., Savage M. i wsp. Takotsubo cardiomyopathy: an Australian single centre experience with medium term follow up. Intern. Med. J. 2012; 42: 3542.

11. Weihs V., Szucs D., Fellner B. i wsp. Stress-induced cardiomyopathy (takotsubo syndrome) in Austria. Eur. Heart J. Acute Cardiovasc. Care 2013; 2: 137-146.

12. Ribeiro V.F., Vasconcelos M., Melao F. i wsp. Short and long-term outcome of stress-induced cardiomyopathy: what can we expect? Arq. Bras. Cardiol. 2014; 102: 80-85.
13. Nunez-Gil I.J., Molina M., Bernardo E. i wsp. Takotsubo syndrome and heart failure: long-term follow-up. Rev. Esp. Cardiol. 2012; 65: 996-1002.

14. Chan C., Troughton R., Elliott J. i wsp. One year follow-up of the 2011 Christchurch Earthquake stress cardiomyopathy cases. NZ Med. J. 2014; 127: 15-22.

15. Parodi G., Bellandi B., Del Pace S. i wsp. Natural history of tako-tsubo cardiomyopathy. Chest 2011; 139: 887-892.

16. Zalewska-Adamiec M., Bachorzewska-Gajewska H., Tomaszuk-Kazberuk A. i wsp. Takotsubo cardiomyopathy: serious early complications and two-year mortality - a 101 case study. Neth. Heart J. 2016; 24: 511-519.

17. Gopalakrishnan M., Hassan A., Villines D. i wsp. Predictors of shortand long-term outcomes of takotsubo cardiomyopathy). Am. J. Cardiol. 2015; 116: 1586-1590.

18. Brinjikji W., El-Sayed A.M., Salka S. In-hospital mortality among patients with takotsubo cardiomyopathy: a study of the National Inpatient Sample 2008 to 2009. Am. Heart J. 2012; 164: 215-221.

19. Kwon S.W., Kim B.O., Kim M.H. i wsp. Diverse left ventricular morphology and predictors of short-term outcome in patients with stressinduced cardiomyopathy. Int. J. Cardiol. 2013; 168: 331-337.

20. Lee P., Song J., Sub B. Outcomes of patients with stress induced cardiomyopathy diagnosed by echocardiography in a tertiary referral hospital. J. Am. Soc. Echocardiogr. 2010; 23: 766-771.

21. Song B.G., Yang H.S., Hwang H.K. i wsp. The impact of stressor patterns on clinical features in patients with tako-tsubo cardiomyopathy: experiences of two tertiary cardiovascular centers. Clin. Cardiol. 2012; 35: E6-E13.

22. Pant S., Deshmukh A., Mehta K. i wsp. Burden of arrhythmias in patients with takotsubo cardiomyopathy (apical ballooning syndrome). Int. J. Cardiol. 2013; 170: 64-68.

23. El-Battrawy I., Lang S., Ansari U. i wsp. Impact of concomitant atrial fibrillation on the prognosis of takotsubo cardiomyopathy. Europace 2016 Oct 4. pii: euw293 [złożono do druku].

24. Vriz 0., Brosolo G., Martina S. i wsp. In-hospital and long-term mortality in takotsubo cardiomyopathy: a community hospital experience. J. Community Hosp. Intern. Med. Perspect. 2016; 6: 31082. 
25. Stiermaier T., Moeller C., Oehler K. i wsp. Long-term excess mortality in takotsubo cardiomyopathy: predictors, causes and clinical consequences. Eur. J. Heart Fail. 2016; 18: 650-656.

26. Gopalakrishnan M., Hassan A., Villines D. i wsp. Predictors of shortand long-term outcomes of takotsubo cardiomyopathy. Am. J. Cardiol. 2015; 116: 1586-1590.

27. Ghadri J.R., Cammann V.L., Napp L.C. i wsp.; International Takotsubo (InterTAK) Registry. Differences in the clinical profile and outcomes of typical and atypical takotsubo syndrome: data from the International Takotsubo Registry. JAMA Cardiol. 2016; 1: 335-340.

28. Madhavan M., Rihal C.S., Lerman A., Prasad A. Acute heart failure in apical ballooning syndrome (takotsubo/stress cardiomyopathy): clinical correlates and Mayo Clinic risk score. J. Am. Coll. Cardiol. 2011; 57: 1400-1401.

29. Stiermaier T., Möller C., Graf T. i wsp. Prognostic usefulness of the ballooning pattern in patients with takotsubo cardiomyopathy. Am. J. Cardiol. 2016; 118: 1737-1741.

30. Citro R., Rigo F., D’Andrea A. i wsp.; Tako-Tsubo Italian Network Investigators. Echocardiographic correlates of acute heart failure., cardiogenic shock, and in-hospital mortality in tako-tsubo cardiomyopathy. JACC Cardiovasc. Imaging 2014; 7: 119-129.

31. Merli E., Sutcliffe S., Gori M., Sutherland G.G. Tako-tsubo cardiomyopathy: new insights into the possible underlying pathophysiology. Eur. J. Echocardiogr. 2006; 7: 53-61.
32. Parodi G., Del Pace S., Salvadori C. i wsp.; Tuscany Registry of TakoTsubo Cardiomyopathy. Left ventricular apical ballooning syndrome as a novel cause of acute mitral regurgitation. J. Am. Coll. Cardiol. 2007; 50: 647-649.

33. Haghi D., Röhm S., Suselbeck T. i wsp. Incidence and clinical significance of mitral regurgitation in Takotsubo cardiomyopathy. Clin. Res. Cardiol. 2010; 99: 93-98.

34. de Gregorio C., Grimaldi P., Lentini C. Left ventricular thrombus formation and cardioembolic complications in patients with Takotsubo-like syndrome: a systematic review. Int. J. Cardiol. 2008; 131: 18-24 .

35. Elsebr A.A., Prasad A., Bybee K.A. i wsp. Transient cardiac apical ballooning syndrome; prevalence and clinical implications of right ventricular involvement. J. Am. Coll. Cardiol. 2006; 47: 1082$-1083$.

36. Kagiyama N., Okura H., Tamada T. i wsp. Impact of right ventricular involvement on the prognosis of takotsubo cardiomyopathy. Eur. Heart J. Cardiovasc. Imaging 2016; 17: 210-216.

37. Finocchiaro G., Kobayashi Y., Magavern E. i wsp. Prevalence and prognostic role of right ventricular involvement in stress-induced cardiomyopathy. J. Card. Fail. 2015; 21: 419-425.

38. Fitzgibbons T.P., Madias C., Seth A. i wsp. Prevalence and clinical characteristics of right ventricular dysfunction in transient stress cardiomyopathy. Am. J. Cardiol. 2009; 104: 133-136. 